\title{
SACRAL NEUROMODULATION FOR THE TREATMENT OF FAECAL INCONTINENCE: FIRST STEPS IN LITHUANIA
}

\author{
Saulius Švagždys', Mantas Vilčinskas², Justinas Vencius², Andrius Radžiūnas ${ }^{\mathbf{3}}$ \\ ${ }^{1}$ Clinic of Surgery, Lithuanian University of Health Sciences Kaunas, Lithuania, \\ ${ }^{2}$ Medical Academy, Faculty of Medicine, Lithuanian University of Health Sciences Kaunas, \\ Lithuania, ${ }^{3}$ Clinic of Neurosurgery, Lithuanian University of Health Sciences Kaunas, Lithuania
}

Key words: faecal incontinence, sacral nerve neuromodulation, percutaneous tibial nerve neuromodulation.

\section{Summary}

Two female patients with faecal incontinence resistant to conservative treatment but improved after percutaneous tibial nerve neuromodulation were treated with sacral nerve neuromodulation in 2014. Quality of Life questionnaires were used in order to determine the impact of faecal incontinence on everyday life before and after the implantation of the stimulator. To evaluate the functional state, Wexner's questionnaires were applied. Bowel movement diary was used to detect the improvement of faecal continence before and after temporary and permanent neuromodulation. The data were analyzed using a Statistical Package for Social Sciences program (SPSS, version 22.0). All values were given as mean $\pm \mathrm{SD}$. $P$-values less than 0.05 were accepted to indicate statistical significance.

Both patients had a reduction in episodes of incontinence and soiling during a 3 week temporary nerve stimulation period as well as during 3 week followup after permanent stimulator implantation. Statistically significant elevation of faecal urgency frequency $(p=0.031)$ was observed during temporary nerve stimulation. Reduction of episodes of faecal incontinence $(p=0.001)$ and soiling $(p=0.000)$ was observed after permanent stimulator implantation. Both patients presented an improvement in lifestyle, coping, depression and embarrassment as well as an improvement in functional state 3 weeks after the beginning of sacral nerve stimulation.

Conclusions: The first results of sacral neuromodulation in patients with faecal incontinence are excellent and very promising.
What does this paper add to the literature? The article describes the first Lithuanian experience applying the sacral nerve neuromodulation to treat faecal incontinence.

\section{Introduction}

Faecal incontinence (FI) is an accidental loss of solid or liquid stools. It is a common problem with up to 10 per cent of adults experiencing some degree of involuntary loss of stool. However, this disabling condition is often under-reported because of fear and embarrassment. Most FI is caused by an interaction of various pathophysiological factors, including abnormal anorectal sensation, colorectal motility as well as anatomical changes to the pelvic floor and sphincter complex [1-2]. Nevertheless, it mainly affects females as a result of direct damage to the anal sphincter(s) or indirect damage caused by stretching of the pudendal nerve during childbirth [3]. This common problem, which persists especially in older population, leads to physical and psychological disability and social isolation. FI is likely to be an even greater problem in the future since the population is getting older [4]. Conservative treatment methods (following the regiment and diet, biofeedback etc.) may not always be effective; therefore, surgical intervention or other treatment methods could be needed. There are several established and evolving interventions and neuromodulation is one of them. It is considered to be a quite effective procedure, which can sometimes replace direct surgical reconstruction of the anal sphincter even in patients with sphincter defects. Sacral nerve neuromodulation (SNM) is now considered to be the best established neuromodulatory therapy for FI [5]. SNM, which was initially developed for the treatment of urinary dysfunction, has now been used for years as a safe effective treatment of FI. The first results of randomized trial of FI treatment by SNM was published by Matzel KE et al in Lancet in 1995 [6]. The exact mecha- 
nism of action is unclear. However, it is felt that SNM may modulate rectal sensation activating or deactivating chemical mediating receptors [7]. SNM is also thought to stimulate the afferent pathway and change brain activity relevant to the continence mechanism [8]. Despite its recent introduction in coloproctology, this procedure is progressively replacing most of the older ones [9-10]. It is less invasive when compared with other techniques and it permits a 2 to 3 week period of temporary stimulation, offering an opportunity to assess its efficacy before proceeding to permanent implantation of a neuromodulation device [11-12]. Sacral neural modulation has gained popularity and acceptance owing to the advantages of a minimally invasive technique, well cited success rates (approximately 70 per cent) [13], minimal morbidity (overall complications range from 5 to

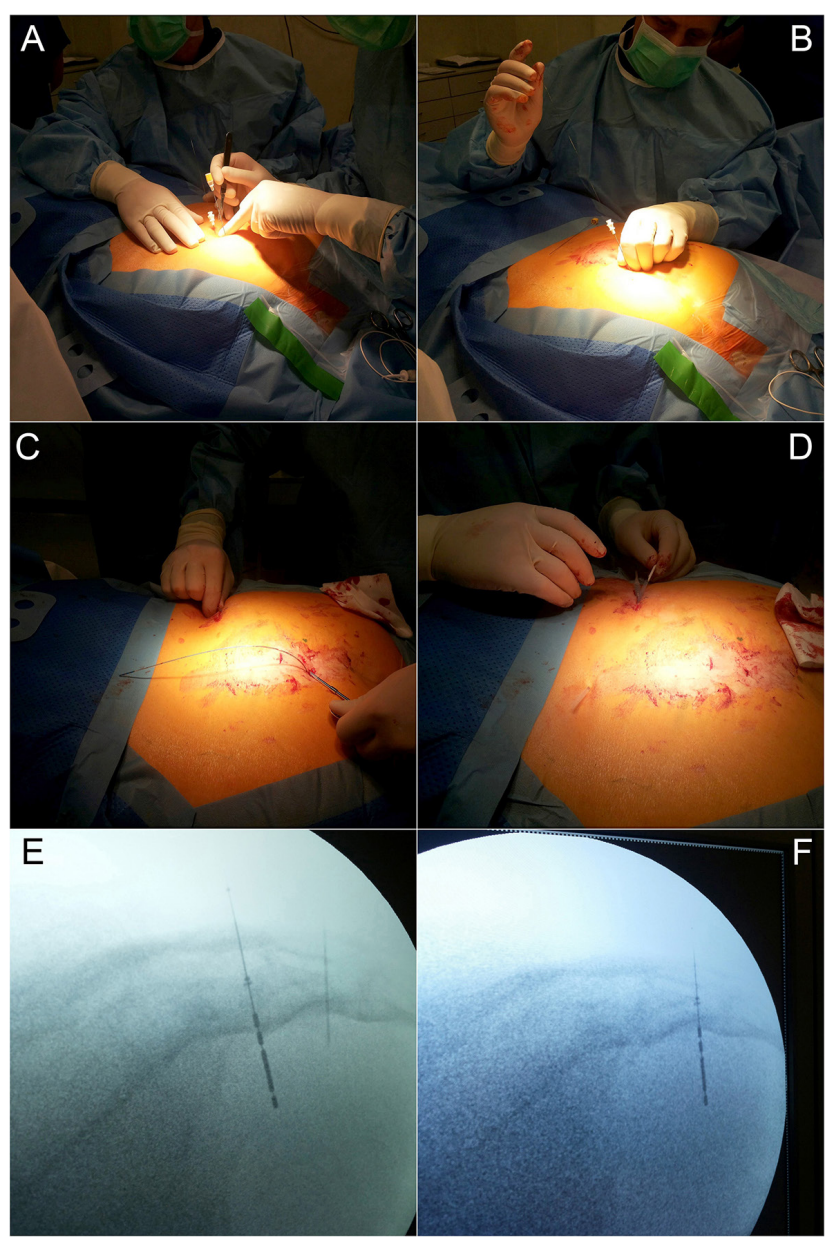

Fig. 1 Technique of PNE

A Introducing tentative needles; $\mathbf{B}$ An electrode is introduced through a tentative needle; $\mathbf{C}$ Introduced electrode; $\mathbf{D}$ An electrode is introduced to the skin through a subcutaneous tunnel; $\mathbf{E}$ The introduced tentative needle and the electrode are seen on the X-ray; $\mathbf{F}$ Final X-ray after completing the procedure.
26 per) [14] and no reported mortality [15]. However, this method of treatment is expensive and not covered by public health insurance in Lithuania. For the last three years, percutanial tibial nerve neuromodulation (PTNM) has been applied as a cheaper, less effective and convenient alternative in our clinic. Positive results of PTNM were considered as an indication to treat two patients by SNM because we have limited possibility of applying this method to more patients and we wanted to lower the risk of our first procedure failure. The aim of this article is to share the first experience of SNM in the Clinic of Surgery, Lithuanian University of Health Sciences and evaluate the effectiveness of this treatment method for patients with FI.

Aim: to assess and present results of sacral nerve neuromodulation - the new method of faecal incontinence treatment in Lithuania, which was applied for two patients suffering from faecal incontinence.

\section{Methods}

Patients. In 2014, PTNM was applied to two female patients with faecal incontinence resistant to conservative treatment. One patient suffered FI after a neurosurgical operation; the second patient had mixed origin of FI. Both of them had a high benefit from PTNM and were selected to sacral nerve neuromodulation in the Clinic of Surgery, Lithuanian University of Health Sciences Kaunas.

The inclusion criteria were age over 18 years, faecal incontinence with solid or liquid stool, failed conservative therapy and a good response to PTNM treatment. The exclusion criteria were mental illness, active oncological process, no response to PTNM treatment and no patient consent.

Intervention. SNM was performed according to the standard two-stage procedure protocol [16]. Under local anesthetic, the patients underwent unilateral peripheral nerve evaluation (PNE) with the percutaneous insertion of a temporary, unipolar stimulation lead to the $\mathrm{S} 3$ or $\mathrm{S} 4$ sacral foramen nearby the nerve root and stimulation effects on toe and external anal sphincter contraction were asses-

Table. 1 Results of patient's dairies of faecal incontinence *- $P$-values less than 0.05

\begin{tabular}{|l|c|c|c|}
\hline Criteria & $\begin{array}{c}\text { Before treat- } \\
\text { ment }\end{array}$ & During TNS & $\begin{array}{c}\text { After in- } \\
\text { sertion of } \\
\text { permanent } \\
\text { stimulator }\end{array}$ \\
\hline Defecation & $1.93 \pm 0.858$ & $1.03 \pm 0.628^{*}$ & $1.02 \pm 0.520^{*}$ \\
\hline Faecal urgency & $0.32 \pm 0.548$ & $0.55 \pm 0.501^{*}$ & $0.33 \pm 0.474$ \\
\hline Incontinence & $0.57 \pm 0.634$ & $0.19 \pm 0.399^{*}$ & $0.14 \pm 0.354^{*}$ \\
\hline Soiling & $1.75 \pm 1.005$ & $1.70 \pm 1.925$ & $0.20 \pm 0.645^{*}$ \\
\hline
\end{tabular}


sed. The electrode that made the best stimulation effect was replaced with a quadripolar lead near to a target nerve. The lead was connected to an external pulse generator for temporary nerve stimulation (TNS). The test electrode was kept in situ for 3 weeks. During this period, both patients demonstrated about $50 \%$ reduction in FI episodes and expressed their satisfaction with the treatment. All data about the quality of life, severity of faecal incontinence and FI frequency were collected and assessed. The response to the temporary treatment was good; therefore, a permanent stimulator was offered to both patients in order to undergo the second stage of treatment. One month after the first procedure, the implantation of permanent stimulation device was implemented. Under local anesthetic, the permanent pulse generator InterStim TWIN Model 7427T was connected to the quadripolar electrode via an extension wire subcutaneously. After the asessment of good responce to the permanent stimulator action, a subcutaneus pocket in the gluteal area was made for the permanent stimulator. The insertion of the electrodes and acute PNE is shown in Figure 1.

Assessment. Faecal incontinence was evaluated based on the patient's bowel movement diaries, which they had to fill during 2 weeks before the treatment, 3 weeks during the TNS and 3 weeks after the permanent stimulator insertion. In the diaries, patients had to mark their daily frequency of defecation (distinguishing faecal urgency), incontinence and soiling. The effectiveness of the treatment towards

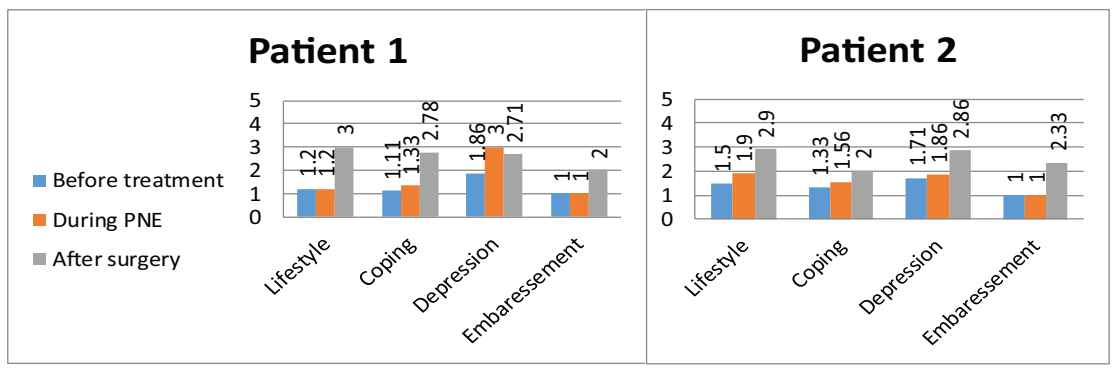

Fig. 2 Results of QOL questionnaire for patient No. 1 and 2

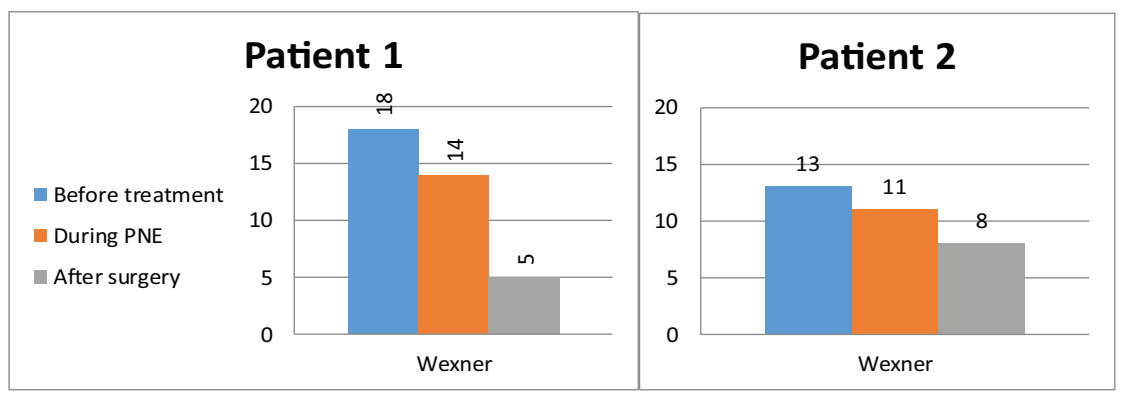

Fig. 3 Results of Wexner's questionnaire for patient No. 1 and 2 the quality of life was evaluated using the Quality of Life (QOL) questionnaire. According to this questionnaire, the quality of life is evaluated based on 4 criteria: lifestyle, coping/behaviour, depression and embarrassment on a scale from 1 to 4, where 1 is the worst condition [17]. The severity of faecal incontinence was evaluated in most of the literature utilizing the Cleveland Clinic Faecal Incontinence or Wexner Score. Wexner score rates the severity of FI on a scale from 0 to 20 , with a higher score indicating more severe complaint [18].

Statistical analyses. The data were analyzed using the Statistical Package for Social Sciences program (SPSS, version 22.0). All values were given as mean \pm SD. MannWhitney test was used to determine if there is any association between two independent samples of non-parametric values. $P$-values less than 0.05 were accepted to indicate statistical significance.

\section{Results}

Both patients had a reduction in episodes of incontinence and soiling during a 3 week TNS as well as during a 3 week follow-up after permanent stimulator insertion. The results which are presented as mean scores of each criteria are shown in the Table 1.

Comparing results before treatment and during TNS, a statistically significant increase was observed in control of faecal urgency $(p=0.031)$ and reduction of faecal incontinence episodes $(p=0.001)$. Moreover, comparing results before treatment and after permanent stimulator implantation statistically significant reduction was observed in episodes of soiling $(p=0.000)$. Meanwhile, faecal urgency episodes after the implantation of the permanent stimulator returned to a primary state. An improvement of all 4 criteria of quality of life questionnaire was observed. Both patients presented an improvement in lifestyle, coping, depression and embarrassment (Fig.2). They also demonstrated improvement in functional state as it is seen in results of Wexner's scale (Fig.3). Due to a small sample of subjects, it was not possible to determine whether the results are statistically significant; however, there is a visible tendency that the quality of life and functional state improve after treatment. 


\section{Discussion}

This analysis demonstrates our initial experience with SNM. This is the first experience of SNM for FI in the Clinic of Surgery, Lithuanian University of Health Sciences. Our data demonstrate that SNM statistically significantly reduces FI severity by decreasing episodes of incontinence and soiling. We estimated statistically significant increasing of faecal urgency according to patient diary during TNS. This phenomenon could be the sign of the increasing sensitivity of the anus during the beginning of neuromodulation. Follow-up results show that after some time the hypersensitivity, which results faecal urgency, returns to its pre-treatment level. Moreover, our results show that the quality of life became better after treatment. Our first experience and short-term results do not conflict with the literature data. According to the systematic review of the clinical effectiveness of neuromodulation in the treatment of faecal incontinence, published by Thin et al, the initial success rate of sacral neuromodulation was found to be $63 \%$, with a long-term success rate of $54 \%$ [2]. According to literature, sacral neuromodulation shows good long-term results for patients with idiopathic faecal incontinence $[19,20]$. However, not much is known about the effects of sacral neuromodulation in patients with previous anorectal surgery. In his recent study, Schwandner showed that sacral neuromodulation greatly improved symptoms in nine patients with low anterior resection syndrome after rectal resection and radiotherapy for rectal cancer [21]. Despite the fact that a loss in effectiveness of approximately 10 per cent is demonstrated within 5 years, sacral neuromodulation still remains an effective long-term treatment option [2]. However, the high price of SNM remains an obstacle to apply this treatment method widely. Even though there are studies, showing that a treatment strategy, including SNM, is cost saving for each successfully treated patient [22], there is a growing interest in the potentially newer, less invasive and cheaper neuromodulation techniques, such as PTNM and Transcutaneous tibial nerve stimulation (TTNS), in the treatment of FI. For these reasons, we started PTNM in our clinic three years ago and we have treated a small amount of patients. Nevertheless, we could assert the effectiveness of this method. Moreover, the results of PTNM could be a good predicting factor in determining patient's suitability for SNM in the future. The introduced neuromodulation therapies offer an alternative to other treatment methods. SNM could be a good alternative method after unsuccessful sphincteroplasty or even sphincteroplasty could be substituted by SNM [2]. A wider choice of the treatment techniques allows the surgeon to select specific treatment methods for individual patients [23]. Our endeavors are to introduce new treatment methods so we could offer the best treatment option for an individual patient with FI.

\section{Conclusions}

The first results of sacral neuromodulation in patients with faecal incontinence are excellent and very promising. It is a great achievement for our clinic in implementing a new treatment method. We hope that our successful first experience is only the first step of introducing SNM into routine practice.

\section{References}

1. Chiarioni G, Palsson OS, Asteria CR, Whitehead WE. Neuromodulation for faecal incontinence: An effective surgical intervention. World J Gastroenterol 2013;19:7048-54. http:// dx.doi.org/10.3748/wjg.v19.i41.7048

2. Thin NN, Horrocks EJ, Hotouras A, Palit S, Thaha MA, Chan CLH. et al. Systematic review of the clinical effectiveness of neuromodulation in the treatment of faecal incontinence. Br J Surg 2013;100:1430-47. http://dx.doi.org/10.1002/bjs.9226

3. Uludag Ö, Koch SMP, van Gemert WG, Dejong CHC, Baeten CGMI. Sacral Neuromodulation in Patients With Faecal Incontinence: A Single-Center Study. Dis Colon Rectum 2004;47:1350-7.

http://dx.doi.org/10.1007/s10350-004-0589-9

4. Stundienè I, Žeromskas P, Valantinas J. Transcutaneous tibial nerve stimulation for the treatment of faecal incontinence: results of a prospective study. Acta Medica Litu 2014;21. http:// dx.doi.org/10.6001/actamedica.v21i2.2946

5. Thin NN, Taylor SJC, Bremner SA, Emmanuel A V., Hounsome N, Williams NS. et al. Randomized clinical trial of sacral versus percutaneous tibial nerve stimulation in patients with faecal incontinence. Br J Surg 2015;102:349-58.

http://dx.doi.org/10.1002/bjs.9695

6. Matzel K., Stadelmaie U, Gall F., Hohenfellner M. Electrical stimulation of sacral spinal nerves for treatment of faecal incontinence. Lancet 1995;346:1124-7. http://dx.doi.org/10.1016/S0140-6736(95)91799-3

7. Michelsen HB, Thompson-Fawcett M, Lundby L, Krogh K, Laurberg S, Buntzen S. Six years of experience with sacral nerve stimulation for faecal incontinence. Dis Colon Rectum 2010;53:414-21.

http://dx.doi.org/10.1007/DCR.0b013e3181ca7dc2

8. Lundby L, Møller A, Buntzen S, Krogh K, Vang K, Gjedde A. et al. Relief of faecal incontinence by sacral nerve stimulation linked to focal brain activation. Dis Colon Rectum 2011;54:318-23.

http://dx.doi.org/10.1007/DCR.0b013e31820348ac

9. Altomare DF, Rinaldi M, Cuccia F. Sacral Neuromodulation. Pelvic Floor Disord., Milano: Springer Milan; 2010; 349-53. http://dx.doi.org/10.1007/978-88-470-1542-5_46 
10. Falletto E, Ganio E, Naldini G, Ratto C, Altomare DF. Sacral neuromodulation for bowel dysfunction: a consensus statement from the Italian group. Tech Coloproctol 2014;18:53-64. http:// dx.doi.org/10.1007/s10151-013-1002-2

11. Johnson BL, Abodeely A, Ferguson MA, Davis BR, Rafferty JF, Paquette IM. Is sacral neuromodulation here to stay? clinical outcomes of a new treatment for faecal incontinence. $\mathrm{J}$ Gastrointest Surg 2015;19:15-20.

http://dx.doi.org/10.1007/s11605-014-2611-4

12. Matzel KE, Maeda Y. The problematic sacral neuromodulation. Reconstr. Surg. Rectum, Anus Perineum, London: Springer London; 2013; 373-8. http://dx.doi.org/10.1007/978-1-84882-413-3_35

13. Matzel KE. Sacral nerve stimulation for faecal incontinence: its role in the treatment algorithm. Color Dis 2011;13:10-4. http://dx.doi.org/10.1111/j.1463-1318.2010.02519.x

14. Tjandra JJ, Lim JF, Matzel K. Sacral nerve stimulation: an emerging treatment for faecal incontinence. ANZ J Surg 2004;74:1098-106.

http://dx.doi.org/10.1111/j.1445-1433.2004.03259.x

15. Wong MTC, Meurette G, Rodat F, Regenet N, Wyart V, Lehur P-A. Outcome and management of patients in whom sacral nerve stimulation for faecal incontinence failed. Dis Colon Rectum 2011;54:425-32.

http://dx.doi.org/10.1007/DCR.0b013e318200f866

16. Boyle DJ, Murphy J, Gooneratne ML, Grimmer K, Allison $\mathrm{ME}$, Chan CLH. et al. Efficacy of sacral nerve stimulation for the treatment of faecal incontinence. Dis Colon Rectum 2011;54:1271-8.

http://dx.doi.org/10.1097/DCR.0b013e3182270af1

17. Rockwood TH, Church JM, Fleshman JW, Kane RL, Mavrantonis C, Thorson AG. et al. Faecal incontinence quality of life scale. Dis Colon Rectum 2000;43:9-16. http://dx.doi. org/10.1007/BF02237236

18. Jorge MJN, Wexner SD. Etiology and management of faecal incontinence. Dis Colon Rectum 1993;36:77-97.

http://dx.doi.org/10.1007/BF02050307

19. Hull T, Giese C, Wexner SD, Mellgren A, Devroede G, Madoff RD. et al. Long-term durability of sacral nerve stimulation therapy for chronic faecal incontinence. Dis Colon Rectum 2013;56:234-45.

http://dx.doi.org/10.1097/DCR.0b013e318276b24c

20. Mellgren A, Wexner SD, Coller JA, Devroede G, Lerew DR, Madoff RD. et al. Long-term efficacy and safety of sacral nerve stimulation for faecal incontinence. Dis Colon Rectum 2011;54:1065-75.

http://dx.doi.org/10.1097/DCR.0b013e31822155e9

21. Schwandner O. Sacral neuromodulation for faecal incontinence and "low anterior resection syndrome" following neoadjuvant therapy for rectal cancer. Int J Colorectal Dis 2013;28:665-9. http://dx.doi.org/10.1007/s00384-013-1687-8

22. van Wunnik BPW, Visschers RGJ, van Asselt ADI, Baeten CGMI. Cost-effectiveness analysis of sacral neuromodu- lation for faecal incontinence in the Netherlands. Color Dis 2012;14:e807-14.

http://dx.doi.org/10.1111/codi.12002

23. David A. Margolin M. New options for the treatment of faecal incontinence. Ochsner J 2008;8:18-24. http://www.ochsnerjournal.org/doi/abs/10.1043/1524-5012(2008)8\%5B18:NOF TTO\%5D2.0.CO\%3B2

24. Findlay JM, Yeung JM, Robinson R, Greaves H, Maxwell-Armstrong C. Peripheral neuromodulation via posterior tibial nerve stimulation - a potential treatment for faecal incontinence? Ann R Coll Surg Engl 2010;92:385-90. http://dx.doi.org/10.1308/ 003588410X12628812459652

\section{IŠMATU NELAIKYMO GYDYMO REZULTATAI TAIKANT SAKRALINIO NERVO MODULIACIJĄ: PIRMOJI PATIRTIS LIETUVOJE}

S. Švagždys, M. Vilčinskas, J. Vencius, A. Radžiūnas

Raktažodžiai: išmatų nelaikymas, sakralinio nervo moduliacija, perkutaninè blauzdinio nervo stimuliacija.

Santrauka

Darbo tikslas: ịvertinti ir pristatyti sakralinio nervo moduliacijos, kuri buvo taikyta dviem pacientėms dèl išmatų nelaikymo, gydymo rezultatus.

Tyrimo medžiaga ir metodai. Gavus bioetikos leidimą atliktas prospektyvinis tyrimas. Tyrimo objektas - dvi pacientès, kurioms 2014 metais buvo atlikta sakralinio nervo neuromoduliacija. Gyvenimo kokybės (QOL) klausimynai buvo panaudoti siekiant nustatyti išmatų nelaikymo įtaką kasdieniniam gyvenimui prieš ir po stimuliatoriaus implantavimo. Siekiant ịvertinti funkcinę būklę, buvo panaudoti išmatų nelaikymo sunkumo (Weksner) klausimynai. Išmatų nelaikymas taip pat buvo vertinamas pagal pacienčių išmatų nelaikymo dienynus, kuriuos jos turejjo pildyti 2 savaites prieš gydymą, 3 savaites laikinosios stimuliacijos metu ir 3 savaites po nuolatinio stimuliatoriaus implantavimo. Statistinių rezultatų analizè atlikta standartinès programinès įrangos paketu SPSS 22.0. Duomenys pateikti vidurkio reikšme ir standartiniu nuokrypiu ( $\pm \mathrm{SD})$. Dviejų nepriklausomų imčių neparametrinių dydžių analizei naudotas Mann-Whitney U kriterijus. Duomenys laikyti statistiškai reikšmingais, kai $\mathrm{p}<0,05$.

Rezultatai. Abiem pacientėms buvo nustatytas išmatų nelaikymo ir tepliojimo epizodų sumažejjimas tiek laikinosios stimuliacijos metu, tiek po pastovaus stimuliatoriaus implantavimo. Statistiškai reikšmingas primygtinio tuštinimosi padažnejjimas buvo stebėtas laikinosios stimuliacijos metu $(p=0.031)$. Nustatytas statistiškai reikšmingas išmatų nelaikymo $(\mathrm{p}=0.001)$ ir tepliojimo $(\mathrm{p}=0.000)$ epizodų sumažejjimas po nuolatinio stimuliatoriaus implantavimo. Abiem pacientèms stebètas gyvenimo kokybès bei funkcinès būklès pageréjimas praejjus 3 savaitèms po stimuliacijos pradžios.

Išvados. Po sakralinio nervo stimuliatoriaus implantacijos pacientèms pagerèjo funkciniai tuštinimosi rodikliai bei gyvenimo kokybè. Pirmieji sakralinio nervo moduliacijos rezultatai, gydant išmatų nelaikymą, yra puikūs ir daug žadantys.

Adresas susirašinėti: justinui.venciui@gmail.com

Gauta 2016-04-04 